\title{
Extreme spatial variation in the growth and reproductive output of the acorn barnacle Semibalanus balanoides
}

\author{
Mark D. Bertness, Steven D. Gaines, David Bermudez, Eric Sanford \\ Graduate Program in Ecology and Evolutionary Biology, Brown University, Providence, Rhode Island 02912, USA
}

\begin{abstract}
Geographic variation in secondary production can profoundly influence population and community processes yet is rarely studied in benthic marine organisms. In this paper, we document striking variation within and among locations in the growth and reproductive output of the acorn barnacle Semibalanus balanoides and discuss the potential consequences of our results on understanding recruitment and other population processes. Within Narragansett Bay (Rhode Island, USA) barnacle growth and reproduction is far greater than at nearby open coast locations. At comparable tidal heights, recruits in the Bay grew to nearly twice the basal diameter and had almost 10 times the reproductive output compared to recruits on the open coast. Transplant experiments suggest that the high secondary production of Bay barnacles is largely a phenotypic response to high primary production. Within- and among-site patterns in barnacle secondary production associated with enhanced flow velocities were also conspicuous. Barnacles at low tidal heights, in habitats exposed to large tidal currents and in waveexposed habitats, had higher growth and reproduction than barnacles at higher tidal heights or habitats with lower velocities. Water column food concentrations and fluid velocities both strongly influence barnacle growth and reproduction through their combined effects on the flux of food to individuals. Our results imply that predictable variation in food supply rates may lead to important and equally predictable consequences on regional larval production and the density-dependent dynamics of adult benthic populations.
\end{abstract}

\section{INTRODUCTION}

Benthic marine populations in intertidal habitats have been studied extensively, and have contributed disproportionately to our general understanding of marine production and community dynamics. Harsh physical conditions such as heat, desiccation, and osmotic stress can limit population growth and affect spatial distribution patterns, but consumer (Paine 1966, Lubchenco 1978), competitive (Connell 1961, Buss 1986) and cooperative interactions (Hay 1986, Bertness 1989, Stephens \& Bertness 1991) often play a major role in dictating population patterns. Benthic marine populations may also be strongly affected by recruitment processes (Sutherland 1974, Underwood \& Denley 1984, Gaines \& Roughgarden 1985, Roughgarden et al. 1987). Conspicuously absent from this extensive list, however, is consideration of the effects of variation in primary and secondary production on benthic population processes for exceptions see Highsmith 1980, Sebens 1980, Birkeland 1982, Glynn 1988,
Vermeij 1990). Early discussions of population and community processes recognized the potential role of variation in production in molding communities (Connell \& Orias 1964), and patterns of primary production are routinely measured (see Valiela 1984 for review). Yet, ostensibly because primary production has not proven to be amenable to experimental manipulation, many of the consequences of variation in production on marine communities have received little rigorous attention.

Variation in the growth rates of consumers within and among populations could have important consequences. Vulnerability to physical stress (Vermeij 1971), competitive dominance (Buss 1986), and consumer interactions (Paine 1976) are all strongly size dependent and are likely to be sensitive to variation in growth rates. Moreover, increased growth rates in organisms with indeterminate growth can lead to larger individuals with increased reproductive output. As a result, differences in secondary production can lead to differences in reproductive output that may 
influence larval supply. If variation in secondary production is a spatially or temporally predictable feature of marine habitats it may generate a variety of cascading effects on populations and may play a major role in generating community patterns.

Sessile filter feeding organisms are ideal organisms to study the impact of secondary production on marine populations. Unlike mobile organisms, sessile organisms cannot spatially track food resources. In addition, for potentially passive suspension feeders like acorn barnacles (Trager et al. 1990) food supplies may be simply envisioned as the flux of food to individuals - a product of the concentration of potential food and the flow rate of food-laden water. Acorn barnacles are particularly attractive study organisms for this work since their general biology has been extensively studied (e.g. Southward 1987) and we know a great deal about barnacles population biology (e.g. Connell 1961, Wethey 1983, Bertness 1989).

In this paper we examine within- and among-site variation in the growth and reproduction of the northern acorn barnacle Semibalanus balanoides. Specifically, we: (1) document strong regional variation in the growth and reproductive output of populations, (2) test the plasticity of growth and reproduction within and among sites with common source transplant experiments, and (3) examine the importance of flow velocity and water column primary production on secondary production. Our data suggest that barnacle secondary production may be a predictable byproduct of water column production and movement. Spatial variation in these features may strongly influence the larval supply and benthic population processes of barnacles and other marine organisms.

\section{METHODS}

Study sites. We examined Semibalanus balanoides growth and reproduction at 4 sites in southern New England, USA, selected to represent typical exposed open coast and protected bay habitats (Fig. 1). The 2 wave-protected barnacle populations studied were located within Narragansett Bay (Rhode Island) on large $(>2 \mathrm{~m}$ ) boulder surfaces. Of the 2 wave-protected sites the Mt. Hope Bay location (Bertness 1984, 1989) is subject to both minimal wave action and minimal tidal currents, whereas at the Portsmouth location (Stephens $\&$ Bertness 1991) wave action is minimal but the site is subject to strong (up to $0.5 \mathrm{~m} \mathrm{~s}^{-1}$ ) longshore tidal currents due to a restriction in the width of the estuary. At the Newport and Little Compton open coast locations (Fig. 1) wave forces in excess of 7 newtons $\mathrm{m}^{-2}$ are common and the barnacle populations studied were on large rock benches.

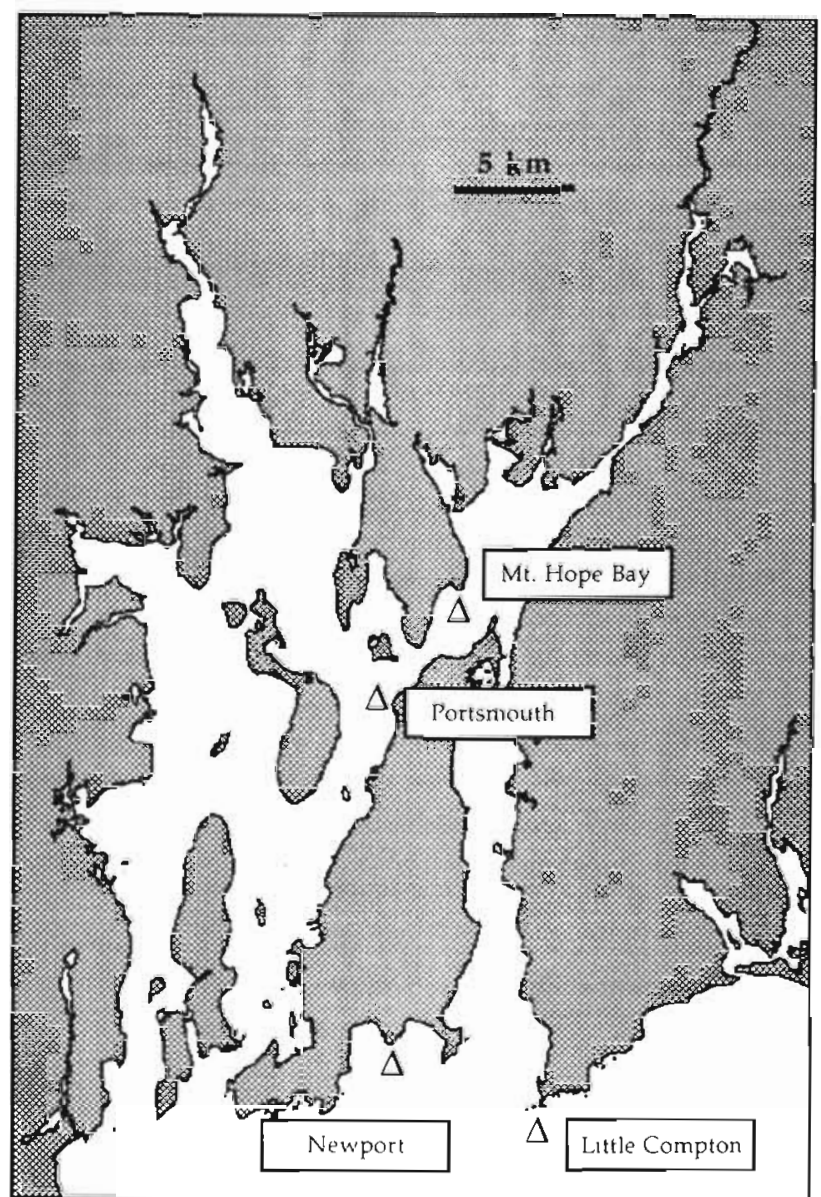

Fig. 1. Narragansett Bay region (Rhode Island, USA) showing the location of our study sites within the Bay (Mt. Hope Bay and Portsmouth) and on the open coast (Little Compton and Newport). Exact sampling locations are marked with triangles

Among-site variation in barnacle secondary production. Growth rate variation in Semibalanus balanoides among sites was examined by monthly sampling from May to September 1990. In southern New England larval settlement occurs between February and April (Bertness et al. 1991). Following settlement at each site we haphazardly collected solitary juveniles each month at high and low tidal heights (Bertness 1989). Only solitary barnacles were sampled to quantify growth and reproduction variation without potentially confounding effects of crowding. We will address the effects of the growth rate variation documented in this paper on bamacle density-dependent processes elsewhere (Bertness \& Gaines unpubl.). To ensure that the individuals collected were 1990 recruits, large $\left(1 \mathrm{~m}^{2}\right)$ areas at each site and tidal height were cleared of all barnacles in January before 1990 settlement. We also randomly thinned recruits in these areas throughout the season to maintain a supply of solitary individuals unaffected by crowding. Collec- 
tions were made during the first suitable low tides of each month and individual barnacles were harvested from rock surfaces with a razor blade. We measured and dissected a random group of individuals (16 to 20) from each site and tidal height. Shell basal diameter and height was measured with calipers (to $0.1 \mathrm{~mm}$ ) and soft tissue and shell were separated under a dissecting microscope $(10 \times)$. Tissue and shell components of each individual were dried and weighed to $\pm 0.01 \mathrm{mg}$. Since basal diameter was found to be an excellent predictor of soft tissue weight $\left(R^{2}=0.89, p<0.001\right)$, we will present most of our result in terms of basal diameters only.

We quantified the reproductive output of individuals at the study sites immediately prior to larval release. In December we haphazardly collected solitary juveniles (i.e. 1990 cohort) and adults at high and low tidal heights at each site. Only solitary individuals were used for the reproductive sampling since crowding strongly affects barnacle morphology and reproductive output (Wethey 1984). We measured and dissected these individuals as described above $(n=16$ to 20 per situation), but also separated soft tissue into somatic tissue and eggs before drying and weighing.

To control for potential genetic differences among sites affecting growth and reproduction, we also transplanted recently metamorphosed juveniles from a common site to all the study sites. In April 1990 small (100 to $200 \mathrm{~cm}^{2}$ ) flat ( 2 to $5 \mathrm{~cm}$ thick) cobbles from Portsmouth with recently metamorphosed Semibalanus balanoides recruits were transplanted to high and low tidal heights at each site. Settlers on each cobble were thinned to low densities (ca 1 settler $\mathrm{cm}^{-2}$ ). Transplant cobbles were attached to horizontal surfaces with epoxy and then mortared into a matrix of cement to buffer them from thermal extremes (see Bertness 1989). Transplanted cobbles were photographed monthly (June to September 1990). Basal diameters of transplanted recruits were measured from photographs while the reproductive output of transplanted recruits was determined for individuals collected in December 1990 .

Wave exposure effects on barnacle secondary production. To test the hypothesis that wave exposure influences barnacle growth, we monitored recruits subject to differing degrees of wave exposure at intermediate tidal heights. At Mt. Hope Bay, Portsmouth, and Newport we sampled individuals on vertical waveexposed and protected faces of massive $(>2 \mathrm{~m})$ boulders. At Little Compton we sampled individuals on vertical surfaces on wave-exposed and protected sides of a rock spit ca $15 \mathrm{~m}$ wide. At each site we collected solitary juveniles monthly (June to September) in exposed and protected locations to examine growth rates and in December collected individuals to quantify reproductive output. Areas used to collect these individuals had been cleared of all barnacles the previous December to assure that all individuals collected were from the 1990 cohort.

To control for potential differences between settlers in wave-exposed and protected locations, we transplanted recently metamorphosed recruits from a common source (Portsmouth) to exposed and protected vertical surfaces at each site. These transplants were made to the same areas where we were monitoring wave-exposed and protected natural recruits. Wave exposure transplants were set up and monitored as described above for the among-site transplants.

Primary production and water movement measurements. As a measure of relative food concentrations for barnacles among our study sites we quantified water column chlorophyll a concentrations weekly from May to the first week of September 1990. We collected four $2 \mathrm{l}$ water samples $5 \mathrm{~m}$ offshore at each site at a depth of $15 \mathrm{~cm}$. Samples were immediately filtered, and chlorophyll concentrations were determined photometrically (see Strickland \& Parsons 1968 for methods). Surface water temperatures were also taken at the study sites on all days we sampled chlorophyll concentrations. Water temperature data, however, will not be discussed further since the secondary production variation we observed among sites was very pronounced well before (early June) summer water temperature differences could be detected among our sites (late June). Water temperatures in general have been found to have little real impact on primary and secondary production rates under field conditions (see Valiela 1984 for discussion).

To quantify water movement patterns within and among sites we measured the dissolution of blocks of calcium sulfate (dental chalk, Diekeen Green). This material dissolves at a rate proportional to flow and can be used to estimate water movement patterns (Opdyke et al. 1987, Eckman et al. 1989, Mullineaux \& Butman 1990, Yund et al. 1991). We used size-standardized chalk cylinders $2 \mathrm{~cm}$ tall with a diameter of $7.5 \mathrm{~cm}$ which we cast in plastic mailing tube caps. We sealed the sides and bottom of the columns with polyurethane to prevent dissolution there and maintain a constant exposed erosion surface area. We attached the blocks to wire mesh bases with acrylic silicone cement and bolted the wire bases to rock surfaces in the field. Each chalk block was weighed $( \pm 0.1 \mathrm{~g})$ before deployment and after $4 \mathrm{~d}$ of exposure was dried and reweighed to calculate dissolution.

Biweekly from June-September 1990 (8 dates) we quantified chalk dissolution at mean low water at each site ( 4 blocks site ${ }^{-1}$ date $^{-1}$ ). We also quantified chalk dissolution at wave-exposed and protected locations at each site ( 7 dates, 4 blocks site ${ }^{-1}$ treatment $^{-1}$ date $^{-1}$ ). 
All blocks were placed adjacent to the corresponding barnacle sampling areas.

\section{RESULTS}

\section{Among-site variation in barnacle secondary production}

Recruits at low tidal heights grew to larger sizes than recruits at high tidal heights $(p<0.001$. ANOVA) and recruit growth differed strikingly among sites (Fig. 2; $\mathrm{p}<0.001$, ANOVA). In particular, Semibalanus balanoides recruits from Narragansett Bay (Portsmouth and
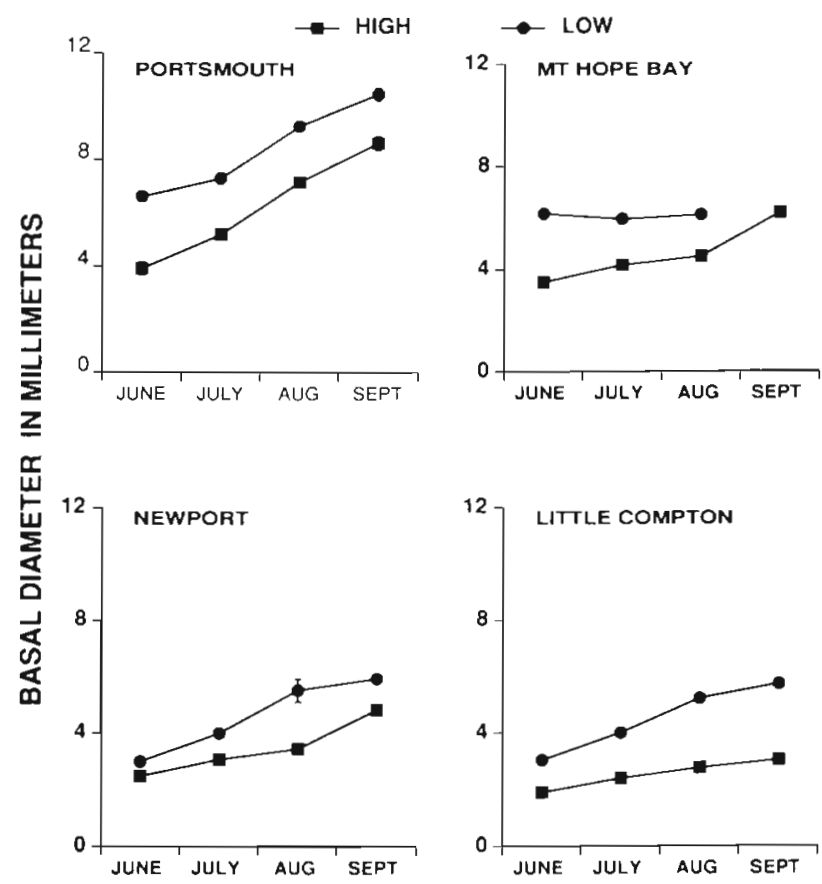

Fig. 2. Semibalanus balanoides. Mean basal diameter of solitary recruits at high and low tidal heights at the 4 study sites. Sample sizes for each point range from 16 to 20 individuals. Standard errors are shown only when they are larger than the symbols

Mt. Hope Bay) grew to larger sizes than recruits at open coast sites (Newport and Little Compton). Differences in bay and open coast recruit growth were most pronounced in the spring (Fig. 2), reflecting the rapid initial increase in barnacle basal diameter in early spring following settlement. Survivorship of solitary barnacle recruits at all sites between April and late June was similar ( $p>0.50$, G-test) and $>85 \%$ (Bertness \& Gaines unpubl.). In June, the basal diameters of recruits at low tidal heights within Narragansett Bay were twice as large as recruits at open coast sites. Over the summer, however, recruits at Portsmouth continued to rapidly grow, while the growth rate of $\mathrm{Mt}$. Hope Bay recruits dropped off markedly (Fig. 2). In Mt. Hope Bay the survivorship and growth of solitary barnacles during the summer is adversely affected at high and low tidal heights by thermal stress and algal overgrowth, respectively (Bertness 1989). At low tidal heights in Mt. Hope Bay algal crust overgrowth annually kills all $S$. balanoides recruits (Fig. 2; also see Bertness 1989). Neither algal crust overgrowth nor thermal stress affects barnacle growth and survival as severely at the other study sites (Bertness \& Bermudez unpubl.).

By September at high tidal heights where a comparison is possible across all study sites (Fig. 2) the basal diameters of recruits at Portsmouth were over $30 \%$ larger than in Mt. Hope Bay ( $p<0.05$, Scheffe test), Mt. Hope Bay recruits were $40 \%$ larger than Newport recruits $(p<0.05$, Scheffe test), and Newport recruits were $32 \%$ larger than Little Compton recruits $(p<0.05$, Scheffe test). Among-site differences in recruit sizes are even more striking comparing tissue weights since Semibalanus balanoides tissue weight increases exponentially with basal diameter $\left(\mathrm{R}^{2}=0.89\right.$, $p<0.001$ ). At high tidal heights in September Portsmouth recruit tissue weights were over $66 \%$ higher than in Mt. Hope Bay (Fig. 3), Mt. Hope Bay recruit

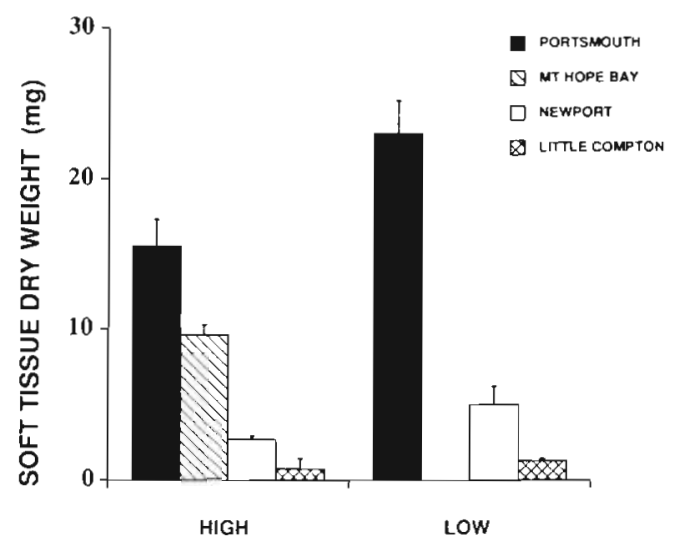

Fig. 3. Semibalanus balanoides. Soft tissue dry weights of solitary recruits (ca 6 mo old) in September 1990 at each of the study sites at high and low tidal heights. Sample sizes are 16 to $20( \pm \mathrm{SE})$

tissue weights were over 3 times larger than at Newport, while Newport recruit tissue weights were over 3 times larger than at Little Compton $(p<0.001$. ANOVA).

Since the total reproductive output (egg dry weight) of Semibalanus balanoides strongly increases with barnacle size $\left(R^{2}=0.85\right)$ and is independent of location $(p>0.25$. ANCOVA), patterns in reproductive output closely parallel growth rate patterns (Fig. 4). Total reproductive output was higher for adults than recruits 

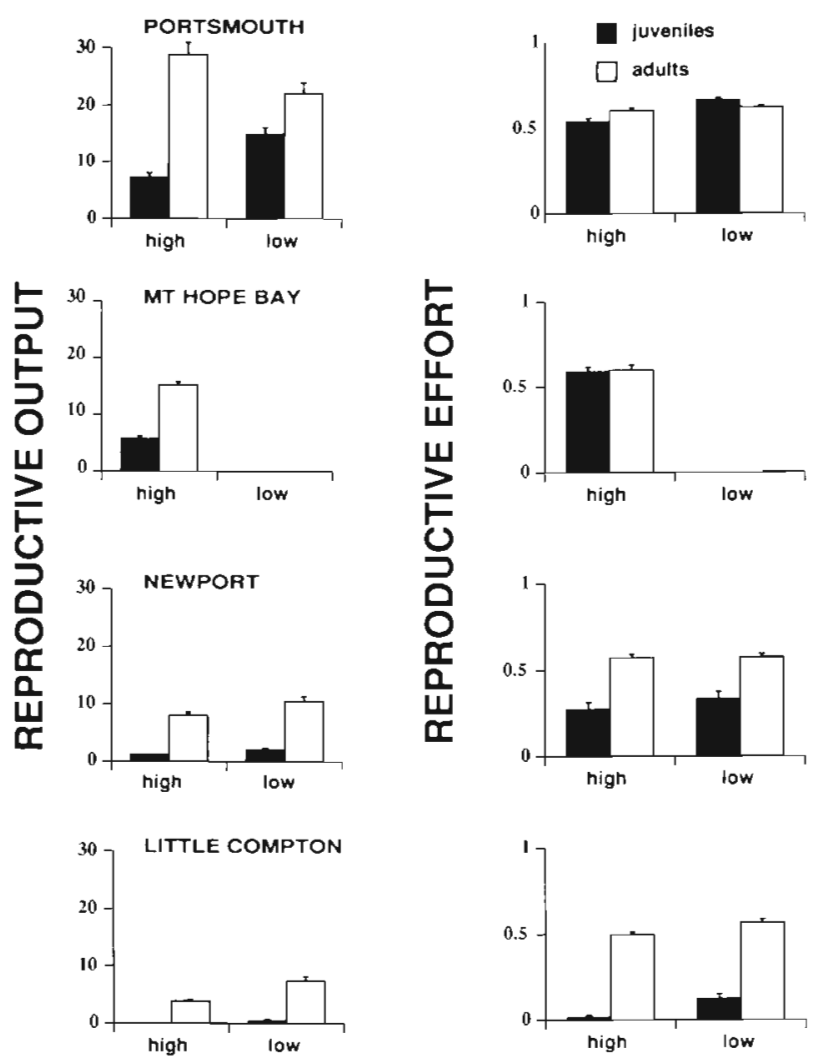

Fig. 4. Semibalanus balanoides. Reproductive output (dried egg weight) and effort (proportion of total soft tissue allocated to eggs) of solitary barnacles at the study sites at high and low tidal heights. Data is given for both haphazardly collected juveniles (young of the year) and adults. Sample sizes range from 16 to 32 ( \pm SE). In Mt. Hope Bay S. balanoides do not survive to reproduce at low tidal heights

$(p<0.001$, ANOVA) and higher at low tidal heights than at high tidal heights $(p<0.001$, ANOVA). Reproductive output also varied markedly among locations for both adults and recruits $(\mathrm{p}<0.001$, ANOVA; both cases). At high tidal heights within Narragansett Bay recruits had $22 \%$ higher ( $p<0.05$, Scheffe test) and adults had $73 \%$ higher ( $p<0.01$, Scheffe test) reproductive output at Portsmouth than at Mt. Hope Bay.

Compared to barnacles within Narragansett Bay, however, the reproductive output of barnacles at open coast locations was extremely low (Fig. 4). At high tidal heights the reproductive output of Newport recruits was only $20 \%$ that of Mt. Hope Bay recruits and recruits at Little Compton had less than $2 \%$ the reproductive output of Newport recruits. Comparable patterns of reproductive output among locations are apparent with adults and at low tidal heights (Fig. 4).

In contrast to barnacle recruits within Narragansett Bay, many recruits at high tidal heights on the open coast did not even reproduce during their first year. At Little Compton, only $6 \%$ of recruits sampled at high tidal heights ( $\mathrm{n}=45$ ) produced eggs their first year whereas at low tidal heights over $93 \%$ of the recruits sampled $(\mathrm{n}=32)$ produced eggs. At Newport $56 \%$ and $100 \%$ of the recruits sampled at high and low tidal heights respectively ( $n=43$ and 32 ) produced eggs their first year. Within Narragansett Bay at both study sites and tidal heights all recruits sampled ( $\mathrm{n} \geq 32$ each case) produced eggs their first year.

The reproductive effort (proportion of dried soft tissue allocated to eggs) of recruits and adults generally paralleled the patterns seen with total reproductive output (Fig. 4). Reproductive effort was generally higher for adults than recruits $(p<0.001$, ANOVA), higher at low tidal heights than at high tidal heights $(p<0.01$, ANOVA), and varied significantly among sites $(p<0.001$, ANOVA). Reproductive effort patterns among locations, in particular, illustrate a sharp dichotomy between barnacles within Narragansett Bay and on the open coast. Whereas the reproductive effort of recruits and adults at Portsmouth and Mt. Hope Bay were similar ( $p>0.05$. Scheffe test), both recruit and adult reproductive effort were higher at bay locations than at open coast sites $(p<0.05$, Scheffe test $)$. Between the open coast sites recruit and adult reproductive effort were both higher $(\mathrm{p}<0.05$, Scheffe tests) at Newport than at Little Compton.

Results of the among-site recruit transplant experiment suggest that much of the variation in Semibalanus balanoides growth and reproduction among sites is environmentally induced (Fig. 5). Survivorship of transplanted recruits did not differ among sites ( $p>0.50, G$-test) and survivorship was very high (85\% overall). Recruit transplant sizes were also initially similar among sites $(p>0.50$, ANOVA). Recruits from the bay, however, grew and reproduced significantly more at low tidal heights than at high tidal heights $(p<0.001$, ANOVA) and growth and reproduction varied significantly ( $p<0.01$, ANOVA) among sites. Among sites, growth, reproductive output, and reproductive effort all decreased with Portsmouth $>\mathrm{Mt}$. Hope Bay $>$ Newport $>$ Little Compton. This ranking perfectly matches the growth and reproductive patterns documented for natural recruits among sites (Figs. $2 \& 4$ )

\section{Wave exposure effecs on barnacle secondary production}

Wave exposure also had striking effects on the growth of Semibalanus balanoides (Fig. 6), but waveexposure effects on barnacle growth varied across the study sites $(p<0.05$, ANOVA, site $x$ exposure interaction). At Mt. Hope Bay, Newport, and Little Compton wave-exposed recruits attained larger sizes than 

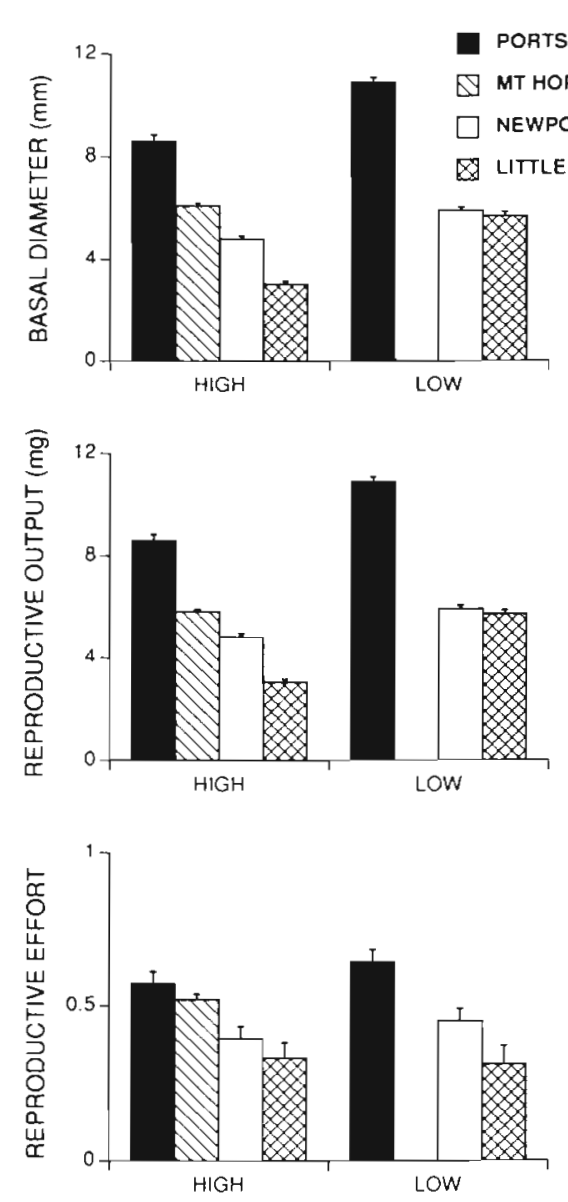

Fig. 5. Semibalanus balanoides. Results of the recruit transplant experiment where recent recruits from Portsmouth were transplanted (in April) to high and low tidal heights at all study sites. Data $(\bar{x} \pm \mathrm{SE}$ ) are given for: (upper) mean basal diameter of solitary individuals ( $\mathrm{n}=16 \mathrm{case}^{-1}$ ) after $5 \mathrm{mo}$ (middle) reproductive output (dried egg weight), and (lower) reproductive effort (the proportion of soft tissue allocated to eggs). All reproductive sampling ( $n=16 \mathrm{case}^{-1}$ ) was done in December No recruits survived at low tidal heights in $M t$ Hope Bay. See text for details

recruits in wave-protected locations $(p<0.05$, Scheffe test each case), while at Portsmouth the growth of recruits on exposed and protected surfaces was similar ( $p>0.05$, Scheffe test).

Both reproductive output and effort of recruits were also affected differentially by wave exposure across the study sites (Fig. 7, p $<0.05$, ANOVA; $_{\text {i }}$ site $\times$ exposure interaction). At Newport and Little Compton reproductive output and effort were greater $(p<0.05$, Scheffe test; each case) on exposed than on protected surfaces, whereas at Portsmouth the reproductive output and effort of recruits on wave-exposed and protected surfaces were similar ( $p>0.50$, Scheffe test each case). Comparable patterns are evident for adult barnacles where data are available (Fig. 7). Solitary adults from

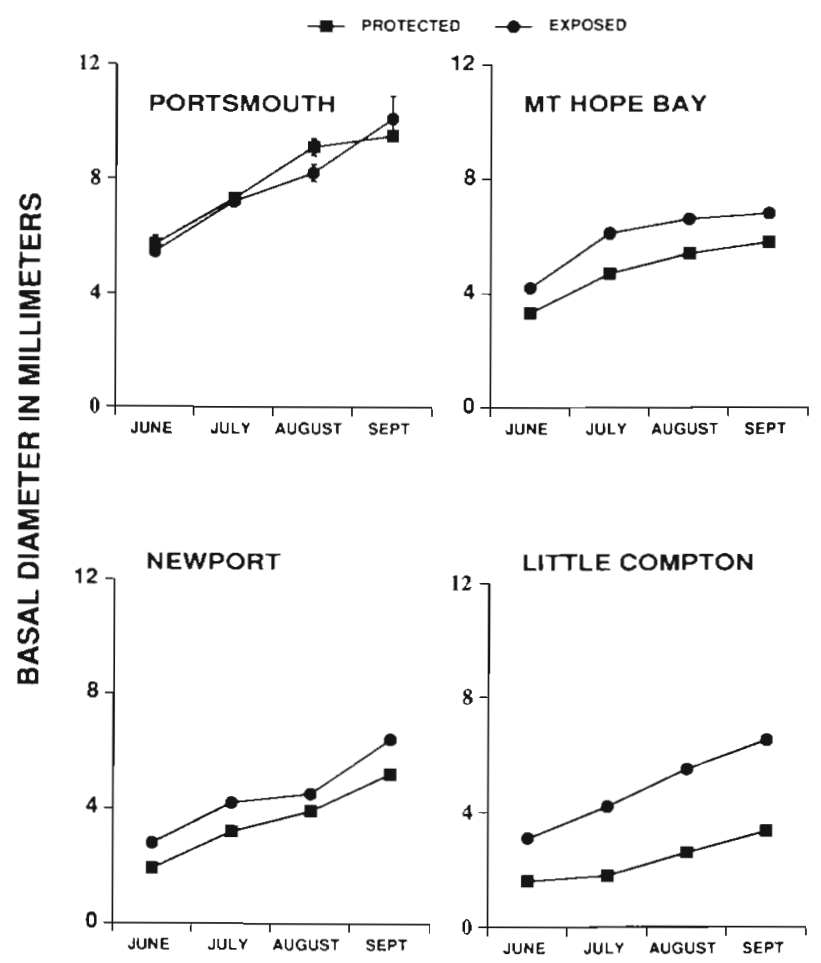

Fig. 6. Semibalanus balanoides. Mean basal diameter ( $\pm \mathrm{SE}$ ) of solitary recruits at intermediate tidal heights in waveexposed and wave-protected locations. Sample sizes for each case are 16 to 20 individuals. Error bars are only shown when larger than the symbols. See text for details

Portsmouth were not available. Reproductive samples from the Mt. Hope Bay exposure areas were lost.

The wave exposure transplant experiment (Fig. 8) mirrored the patterns seen with natural recruits. Survivorship of these transplants was high $(>80 \%)$ and similar among sites and wave exposure locations. Wave exposure effects on the growth and reproduction of the transplanted recruits varied across sites $(p<0.05$, ANOVA; exposure $\times$ site interaction for size, reproductive output and reproductive effort). Moreover, as with natural recruits, the growth, reproductive output, and reproductive effort of transplanted recruits were increased with wave exposure at Newport and Little Compton ( $p<0.05$, Scheffe test each case), but not at Portsmouth ( $p>0.05$, Scheffe test; each case).

\section{Primary production and water movement}

Average weekly (May to September) chlorophyll concentrations from the sites (Fig. 9) reveal a sharp dichotomy in the primary production between Narragansett Bay and nearby coastal waters $(p<0.01$, ANOVA). Chlorophyll concentrations at the Narragansett Bay sites were nearly 6 times higher than at open 


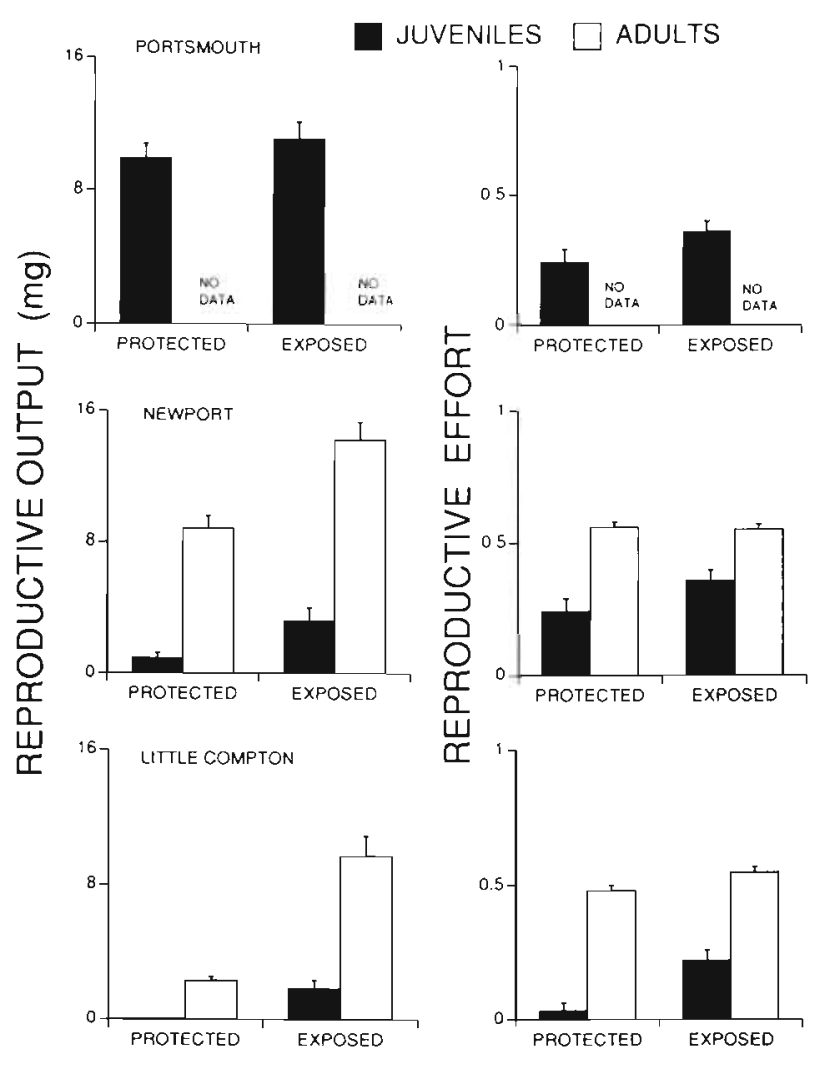

Fig. 7. Semibalanus balanoides. Mean ( $\pm \mathrm{SE}$ ) reproductive output (dried egg weight) and effort (proportion of soft tissue allocated to eggs) of solitary barnacles at intermediate tidal heights in wave-exposed and wave-protected locations. Data are given for haphazardly collected juveniles (young of the year) and adults ( $n=16$ to 32 each case). Solitary adults at intermediate tidal heights were not available at the Portsmouth site

coast sites, while chlorophyll concentrations were similar at sites within the bay and on the open coast ( $p>0.05$. Scheffe test, each case).

Chalk dissolution data (Fig. 10) also reveal significant differences among sites in water movement patterns $(p<0.01$, ANOVA). Chalk dissolution was highest at Newport ( $p<0.05$, Scheffe test), intermediate at Little Compton and Portsmouth and lowest in Mt. Hope Bay. These data illustrate expected differences in water movement between open coast habitats (Little Compton and Newport) and protected bays (Mt. Hope Bay). but also reveal that areas within Narragansett Bay exposed to heavy tidal currents (Portsmouth) can experience high flows.

Chalk dissolution data from wave-exposed and protected locations within the study sites illustrate both within- and among-site water movement patterns (Fig. 10). Both wave exposure ( $p<0.01$, ANOVA) and site $(p<0.05$, ANOVA) influenced chalk dissolution, and wave exposure effects varied across the study sites $(p<0.05$, ANOVA; site $\times$ exposure interaction). Not
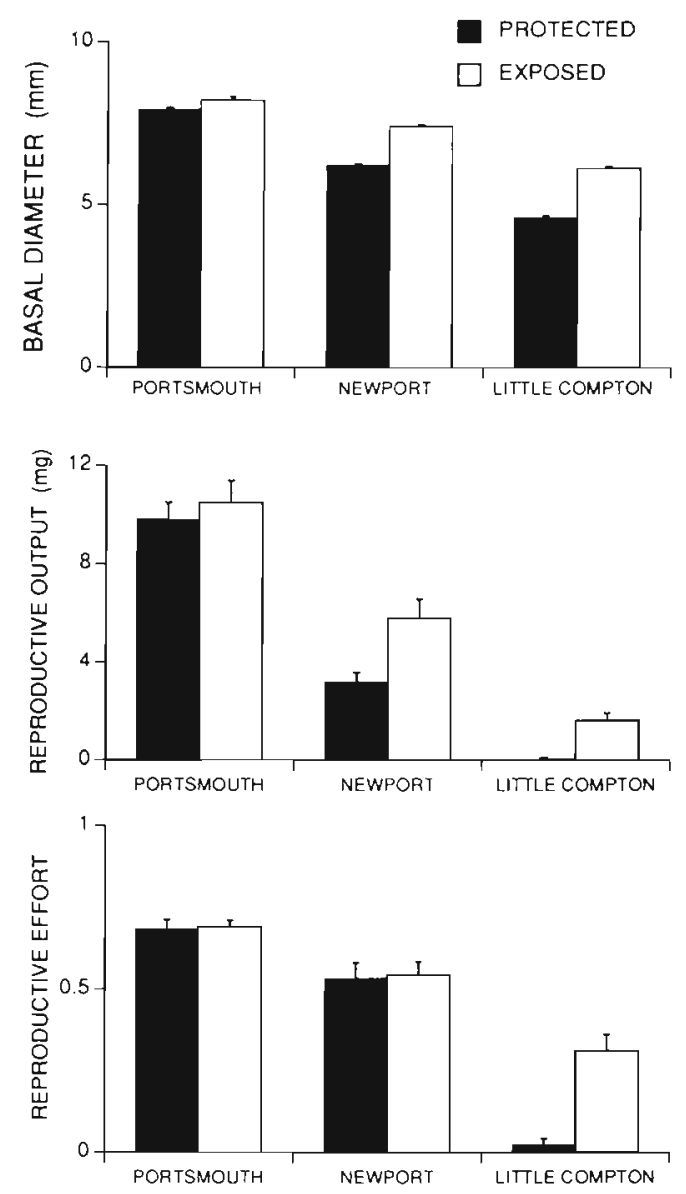

Fig. 8. Semibalanus balanoides. Results of the transplant experiment where cobbles with recruits from Portsmouth were transplanted in April to wave-exposed and protected locations at all the study sites. Data $(\overline{\mathrm{x}} \pm \mathrm{SE})$ are given for basal diameters after 5 mo, and reproductive output and effort of 16 to 20 randomly collected solitary individuals. Data from Mt. Hope Bay were lost. See text for details

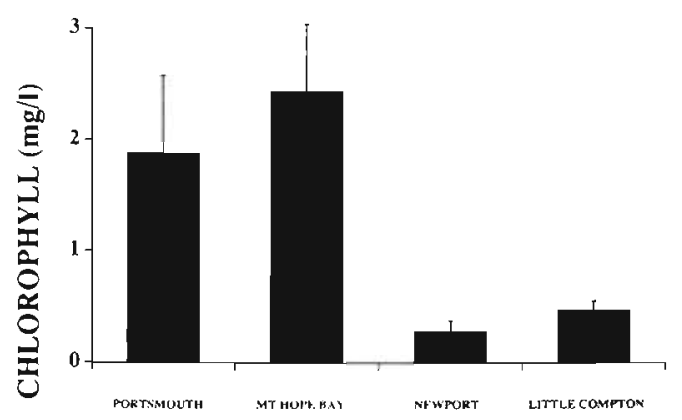

Fig. 9. Water column chlorophyll a concentrations from the study sites (May to September 1991). Data are means of average values from sampling ( $\mathrm{n}=9$ sampling dates) every 10 to $14 \mathrm{~d}( \pm \mathrm{SE})$. See text for methods and discussion

surprisingly, highest chalk dissolution rates were found in wave-exposed locations on the open coast, while lowest chalk dissolution values were found in waveprotected locations at the most protected bay site (Mt. 


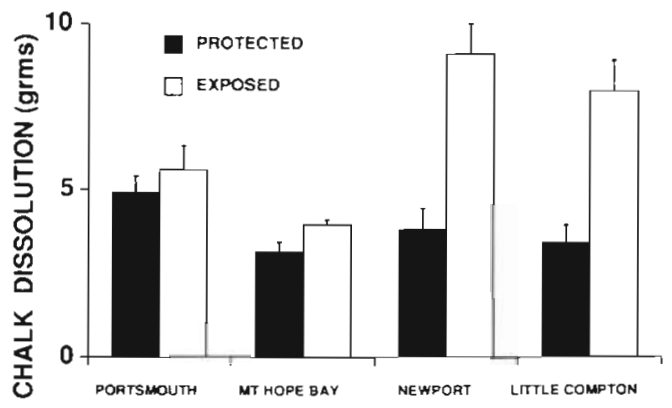

Fig. 10. Chalk dissolution (daily rates) at wave-exposed $(\mathrm{n}=4)$ and wave-protected $(\mathrm{n}=4)$ locations at the study sites ( $\mathrm{n}=7$ sampling dates, $\pm \mathrm{SE}$ ). See text for detailed methods

Hope Bay). At Portsmouth, chalk dissolution was high on both wave-exposed and protected surfaces illustrating the dominance of tidal currents in water movement patterns at this site.

\section{DISCUSSION}

Our results demonstrate striking within- and amongsite variation in the growth and reproduction of acorn barnacles and suggest that barnacle secondary production is enhanced by high primary production and water velocities. These findings imply that local and regional patterns in barnacle growth and reproduction may be predictable products of food supply rates and have a number of important consequences for understanding the population dynamics of barnacles and other feeding marine organisms.

\section{Mechanisms of growth and reproductive variation}

Semibalanus balanoides is a facultative active suspension feeder since it is capable of either actively driving water through its feeding cirri or simply extending its feeding cirri into ambient currents to passively collect food (LaBarbera 1984). Recent laboratory studies have confirmed that $S$. balanoides actively suspension-feeds at low current velocities, but passively suspension-feeds at high current velocities (Tragner et al. 1990). Our results suggest that barnacle feeding efficiency, growth, and reproduction are functions of water column food concentrations and the delivery rate of food to individuals by local water currents. Chlorophyll concentrations were nearly 6 times higher within Narragansett Bay than at nearby coastal sites (Fig. 9) and barnacles from Narragansett Bay had higher growth and reproductive outputs than barnacles from open coast locations (Figs. 2 \& 4). High chlorophyll concentrations in Narragansett Bay probably reflect high primary production resulting from high nutrient inputs. Due to high nutrient inputs, bays and estuaries may generally have higher primary and secondary production than nearby coastal waters (see Nixon 1980 for review).

Exposure to high flow also appears to be an important cause of variation in secondary production among as well as within locations (also see Cancino \& Hughes 1987, Best 1988). Within locations, barnacles on waveexposed surfaces grew faster and had higher reproductive outputs in comparison to individuals on waveprotected surfaces (Figs. 6 \& 7) except at Portsmouth where water movement was dominated by long-shore tidal currents. Among locations, sites exposed to high current velocities (such as Portsmouth) or high wavegenerated velocities may generally be areas of elevated growth and reproduction for passive suspension feeders. Geomorphological (e.g. seamounts, Witman \& Arnold 1989; estuary constrictions, our Portsmouth site) and biological (e.g. kelp beds, Eckman et al. 1989) aspects of habitats that influence hydrodynamics in general may have strong repercussions on suspension feeder fitness. Moreover, since in contrast to passive suspension feeders active suspension feeders may be inhibited by increased current velocities (LaBarbera 1984, Eckman et al. 1989), local hydrodynamics may influence the growth and reproduction of passive and active suspension feeders differently.

\section{Consequences of regional and local variation in growth and reproduction}

Massive variation in the growth and reproduction of barnacles within and among locations may have a number of important implications for understanding the population biology of barnacles and other sessile filter feeders with complex life cycles. Like many benthic invertebrates, acorn barnacles have planktonic larvae that spend a number of weeks in the water column. Planktonic larval development can potentially decouple local population success from local recruitment, and thus finding substantial among-site variation in reproductive output has important ramifications for understanding the size and composition of local and regional larval pools. Moreover, since competition for space among sessile invertebrates can be strongly influenced by growth rates (Buss 1986), the dynamics of benthic populations may vary predictably among sites as a function of differences in secondary production.

Both within- and among-site patterns in the reproductive output of acorn barnacles may have important consequences for understanding larval supplies to 
benthic populations. Within sites we found that potential reproductive output increased dramatically with decreasing tidal height (Fig. 4) and increasing exposure to flow (Fig. 6). While barnacle crowding and mortality could dramatically influence these patterns this suggests that within sites low intertidal individuals and individuals in wave-exposed habitats may contribute disproportionately to local larval supplies

Strong among-site variation in growth and reproductive output reveals that geographic locations may vary substantially in their importance to regional larval supplies. The increased reproductive output of barnacles within bays and estuaries suggests that if barnacle survivorship patterns are similar between coastal and estuarine habitats, bays and estuaries may serve as regional sources and exporters of larvae. Our data also suggest that, on a smaller scale, sites with exceptionally high secondary production (e.g. Portsmouth) may serve as major suppliers of larvae and recruits within a region. What this variation in larval production means to local and regional barnacle populations is entirely dependent on the degree and patterns of larval transport among sites. If larvae produced at different sites are widely transported and mixed before settlement, local populations with high reproductive output may simply contribute disproportionately to regional larval supplies. In contrast, if larval dispersal among sites is limited, variation and reproductive output among sites may lead to parallel variation in larval supply rates among sites. In either case high site variation in reproductive output may dramatically influence regional population processes.

The variation in growth rates we have documented may also lead to very different benthic population processes within and among locations. High growth rates of barnacles can lead to crowding and the modification of individuals into tall, elongate individuals packed into dense aggregations or hummocks (Barnes \& Powell 1950). Crowding can lead to massive mortality under physically benign conditions, but may buffer individuals from physical stress under harsh physical conditions and increase barnacle survivorship (Bertness 1989). Predictable growth rate variation within and among locations may lead to equally predictable within- and among-site variation in density-dependent interactions that may dictate the size of adult population and influence larval production patterns.

We suggest that predictable variation in the secondary production of sessile marine suspension feeders may have a variety of important but unappreciated effects on the population biology of benthic marine organisms. Understanding these issues will require a more regional, comprehensive, and interdisciplinary approach to studying benthic marine populations than is generally taken.

\section{LITERATURE CITED}

Barnes, H., Powell, H. T (1950). The development, general morphology, and subsequent elimination of barnacle populations, Balanus crenatus and Balanus balanoides, after a heavy initial settlement. J. Anim. Ecol. 19: 175-179

Bertness, M. D. (1984). Habitat and community modification by an introduced herbivorous snail. Ecology 65 : 370-381

Bertness. M. D. (1989). Positive and negative density dependent mortality and the population structure of Semibalanus balanoides in a sheltered bay habitat. Ecology 70: 257-268

Best, B. A. (1988). Passive suspension feeding in a sea pen: effects of ambient flow on volume flow rate and filtering efficiency. Biol. Bull. mar biol. Lab., Woods Hole 175: 332-342

Birkeland, C. (1982). Terrestrial runoff as a cause of outbreaks of Acanthaster planci. Mar. Biol. 69: 175-185

Buss, L. W. (1986). Competition and community organization on hard surfaces in the sea. In: Diamond, J., Case, T. J. (eds.) Community ecology. Harper and Row, New York, p. $517-536$

Cancino, J. M., Hughes, R. N. (1987). The effect of water flow on growth and reproduction of Celleporella hyalina (L.) (Bryosoa: Cheilosotomata). J. exp. mar. Biol. Ecol. 112: $109-130$

Connell, J. H. (1961). The influence of interspecific competition and other factors on the distribution of the barnacle Chthamalus stellatus. Ecology 42: 710-723

Connell, J. H., Orias, E. (1964). The ecological regulation of species diversity. Am. Nat. 98: 399-414

Eckman, J., Duggins, D. O., Sewell, A. T. (1989). Ecology of understory kelp environments. I. Effects of kelps on flow and particle transport near the bottom. J. exp. mar. Biol Ecol. 129: 173-187

Eckman, J. G., Peterson, C. H., Cahalan, J. A. (1989). Effects of flow speed, turbulence, and orientation on growth of juvenile bay scallops Argopectin irradians. J. exp. mar Biol. Ecol. 132: 123-140

Gaines, S. D., Roughgarden, J. (1985). Larval settlement rate: a leading determinant of structure in an ecological community of the marine intertidal zone. Proc. natl Acad. Sci USA 82: $3707-3711$

Glynn, P. W (1988). El Niño-southern oscillation 1982-83 nearshore population, community and ecosystem responses. Ann. Rev. Ecol. Syst. 19: 309-345

Hay, M. (1986). Associational defenses and the maintenance of species diversity: turning competitors into accomplices. Am. Nat. 128: 617-641

Highsmith, R. C. (1980). Geographic patterns of coral bioerosion: a productivity hypothesis. J. exp. mar. Biol. Ecol. 46: $177-196$

LaBarbera, M. (1984). Feeding currents and particle capture mechanisms in suspension feeding animals. Am. Zool. 24 $71-84$

Lubchenco, J. (1978). Plant species diversity in a marine intertidal community: importance of herbivore food preference and algal competitive abilities. Am. Nat. 112: 23-39

Mullineaux, L., Butman, C. A. (1990). Recruitment of encrusting benthic invertebrates in boundary-layer flows: a deepwater experiment on Cross Seamount. Limnol. Oceanogr. 35: $409-423$

Nixon, S. W. (1980). Between coastal marshes and coastal waters - a review of twenty years of speculation and research on the role of sall marshes in estuarine productivity. In: Hamilton, P., MacDonald, K. (eds.) Estuarine and wetland processes. Plenum Press, New York, p. 437-525

Opdyke, B. N., Gust, G., Ledwell, J. R. (1987). Mass transfer 
from smooth alabaster surfaces in turbulent flows. Geophys. Res. Lett. 14: 1131-1134

Paine, R. T (1966). Food web complexity and species diversity. Am. Nat. 100: 65-75

Paine, R. T (1976). Size-limited predation: an observational and experimental approach with the Mytilus-Pisaster interaction. Ecology 57: 858-873

Roughgarden, J. S., Gaines, S. D., Pacala, S. (1987). Supply side ecology: the role of physical transport processes. In Organization of communities: past and present. Proceedings of the British Ecological Society. Blackwell Scientific Publications, London, p. 459-489

Sebens, K. P. (1980). The regulation of asexual reproduction and indeterminate body size in the sea anemone. Anthropleura elegantissima. Biol. Bull. mar. biol. Lab., Woods Hole 158: 370-382

Southward, A. J. (ed.) (1987). Barnacle biology. A. A. Balkema Rotterdam

Stephens, E. G., Bertness, M. D. (1991). Mussel facilitation of barnacle survival in a sheltered bay habitat. J exp. mar. Biol. Ecol. 145: 33-48

Strickland, J. D. H., Parsons, T. R. (1968). A practical manual of seawater analysis. Bull. Fish. Res. Bd Can. 167

Sutherland, J. P. (1974). Multiple stability points in natural communities. Am. Nat. 108: 859-872

This article was presented by R. H. Karlson, Newark, Delaware, USA
Tragner, G. C., Hwang, J. S., Strickler, J. R. (1990). Barnacle suspension-feeding in variable flow. Mar. Biol. 105: $117-127$

Underwood, A. J., Denley, E. J. (1984), Paradigms, explanations, and generalizations in models for the structure of intertidal communities on rocky shores. In: Strong, D. R., Simberloff, D., Abele, L., Thistle, A. (eds.) Ecological communities. Princeton Press, Princeton, p. 151-180

Valiela, I. (1984). Marine ecological processes. Springer-Verlag, New York

Vermeij, G. J. (1971). Temperature relationships of some tropical Pacific intertidal gastropods. Mar. Biol. 10: 308-314

Vermeij, G. J. (1990). Tropical Pacific pelecypods and productivity: a hypothesis. Bull. mar. Sci. 47 (1): 62-67

Wethey, D.S. (1983). Geographical limits and local zonation: the barnacles Semibalanus and Chthamalus in New England. Biol. Bull. mar. biol. Lab., Woods Hole 165: 330-34 1

Wethey, D. S. (1984). Effects of crowding on fecundity in barnacles: Semibalanus balanoides, Balanus glandula, and Chthamalus dalli. Can. J. Zool. 62: 1788-1795

Witman, J. D., Amold, C. E. (1989). Larval supply at two offshore pinnacles. Am. Zool. 29: 10

Yund, P. O., Gaines, S. D., Bertness, M. D. (1991). Cylindrical tube traps for larval sampling. Limnol. Oceanogr. (in press)

Manuscript first received: February 21, 1991

Revised version accepted: May 30, 1991 